\title{
Effect of Library Service Quality to Users Satisfaction in The Library of The Faculty of Communication
}

\section{Pengaruh Kualitas Layanan Terhadap Kepuasan Pengguna di Perpustakaan Fakultas Ilmu Komunikasi}

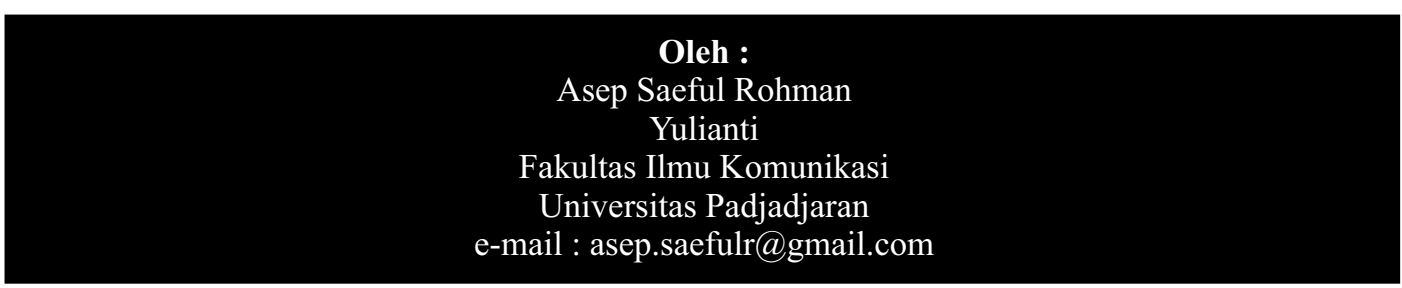

Abstrak. Penelitian ini bertujuan untuk mengetahui pengaruh kualitas layanan terhadap kepuasan pengguna di Perpustakaan Fakultas Ilmu Komunikasi Universitas Padjadjaran. Kualitas layanan ditinjau dari tiga dimensi kualitas layanan menurut Model LibQual ${ }^{+\mathrm{TM}}$ yakni Information Control, Affect of Services dan Library as Place. Kepuasan pengguna ditentukan berdasarkan analisa gap antara persepsi dan harapan pengguna. Pendekatan yang digunakan dalam penelitian ini adalah deskriptif kuantitatif dengan metode survey. Populasi dan sampel dalam penelitian ini adalah pengguna perpustakaan Fikom Unpad. Hasil penelitian menunjukkan bahwa kualitas layanan perpustakaan secara umum belum dapat memberikan kepuasan bagi penggunanya. Nilai Adequacy Gap secara umum yakni masih dibawah nilai rata-rata harapan minimum yakni -0,19. Dimensi yang paling berkontribusi mempengaruhi ketidakpuasan pengguna yakni dimensi Library as Place dengan nilai Adequacy Gap -0,40, dimensi Information Control dengan nilai Adequacy Gap -0,14, kemudian dimensi Affect of Service yang nilai Adequacy Gap negative-nya paling kecil yakni -0,02. Pernyataan yang dinilai memberikan kepuasan bagi pengguna yakni pernyataan tentang aspek pencahayaan didalam ruangan perpustakaan dengan nilai Adequacy Gap positif sebesar 1,69. Sedangkan pernyataan yang paling tidak memuaskan bagi pengguna yakni pada aspek ruangan yang dinilai terlalu sempit bagi ruang gerak pengguna selama didalam perpustakaan dengan nilai Adequacy Gap-nya yakni sebesar -3,29. Perpustakaan Fakultas Ilmu Komunikasi diharapkan berupaya lebih baik untuk dapat meraih kepuasan pengguna dengan cara meningkatkan kualitas layanannya.

Kata Kunci : Kualitas Layanan Perpustakaan, Kepuasan Pengguna, Model
LibQual $^{+\mathrm{TM}}$, Affect of Services, Information Control, Library as Place.

Abstract. This study aims to determine the effect of service quality on user satisfaction in the Library Faculty of Communication Padjadjaran University. The quality of service in terms of service quality according to the three-dimensional model of the LibQual ${ }^{+T M}$ that is Information Control, Affect of Services and Library as Place. User satisfaction is determined by analysis of the gap between perception and expectations of users. The approach used in this research is quantitative descriptive with survey method. Population and sample in this research is the library user of Faculty Communication. The results showed that the quality of library services in general have not been able to give satisfaction to the users. Value Adequacy Gap in general that is still below the average value of the minimum expectations is -0,19. 
Dimensions that contribute most affect the user dissatisfaction that is dimension of the Library as Place with a value Adequacy Gap is -0,40, dimensions Information Control with a value of Adequacy Gap is -0,14, then the dimensions Affect of Service with a value of Adequacy Gap negative is -0,02. The statement is considered to provide satisfaction for users thai is about aspects of lighting in the room with a value of Adequacy Gap positive is 1,69. While the statement is most unsatisfactory for the user that is the aspect of the room which was considered too small for the space for the user during in the library with its value of Adequacy Gap is equal to -3.29. Library of the Faculty of Communication is expected to do a better programme in order to achieve user satisfaction by improving the quality of its services.

Keywords: Quality of Service Libraries, User Experience, LibQual ${ }^{+T M}$ Model, Affect of Services, Information Control, Library as Place. 


\section{PENDAHULUAN}

Saat ini kebutuhan masyarakat terhadap informasi yang cepat, tepat dan akurat sudah tidak bisa ditawar lagi. Masyarakat kita sudah sangat tergantung pada ketersediaan informasi untuk memenuhi berbagai kebutuhan hidup. Untuk itu, perpustakaan sebagai salah satu lembaga yang bergerak dalam jasa penyediaan informasi bagi penggunanya harus sadar betul akan hal ini. Kompleksitas pengguna jasa perpustakaan mengharuskan pihak pengelola perpustakaan atau pustakawan dapat lebih kreatif, inovatif dan aspiratif dalam memenuhi kebutuhan informasi pengguna yang berbeda antara yang satu dengan lainnya. Untuk memenuhi kebutuhan informasi saja tidak cukup tanpa melalui pemberian layanan yang baik menngiat begitu kompleksnya harapan pengguna dalam hal keinginannya untuk dilayani. Karena itu, dalam memberikan/memenuhi kebutuhan informasi pada pengguna di perpustakaan, penerapan konsep layanan yang baik jelas merupakan sesuatu yang tidak bisa ditawar lagi.

Terkait dengan hal diatas, layanan yang baik adalah layanan yang berorientasi kepada pengguna atau pelanggan (Gasperz, 2002: hlm.85). Artinya bahwa layanan yang dilakukan haruslah berorientasi kepada pemenuhan kebutuhan yang diinginkan oleh pengguna. Karenanya untuk menyelaraskan upaya layanan yang dilakukan oleh perpustakaan dalam rangka pemenuhan kebutuhan tersebut harus diketahui apa sebetulnya yang menjadi keinginan atau harapan pengguna agar gap/kesenjangan yang terjadi antara harapan pengguna dengan layanan yang diberikan oleh pihak perpustakaan dapat diatasi semaksimal mungkin. Dengan demikian akurasi keinginan pengguna akan mendekati pada tahap kesesuaian yang lebih tinggi.

Perpustakaan Fakultas Ilmu Komunikasi Unpad adalah perpustakaan tingkat perguruan tinggi yang berada di tingkat Fakultas. Perpustakaan Fakultas Ilmu Komunikasi Unpad merupakan sarana pendukung utama dalam aktifitas akademik di Fikom Unpad. Keberadaan perpustakaan di Fikom Unpad tentunya tidak lepas dari kontribusi masyarakat. Terutama dalam hal ini adalah mahasiswa dan orang tuanya. Hal ini sesuai dengan pendapat yang dikemukakan oleh Soelistyo-Basuki (1997) bahwa perpustakaan diciptakan oleh masyarakat, dari dana masyarakat, dan dengan tujuan utama untuk melayani kepentingan masyarakat.

Dalam hal pemberian jasa perpustakaan, ada dua pihak yang terlibat, yaitu pengguna dengan segala harapan dan kebutuhannya; dan dipihak lain perpustakaan dengan kegiatan penyediaan jasanya. Perpustakaan Fakultas Ilmu Komunikasi Unpad sebagai suatu organisasi nirlaba telah mencanangkan dalam tujuan dan sasarannya berorientasi pada terpenuhinya kebutuhan masyarakat sivitas akademika dan umum akan informasi melalui layanan perpustakaan dengan sasarannya adalah terwujudnya 
layanan informasi yang optimal.

Hubungan antara perpustakaan dan pengguna perpustakaan sangat berpengaruh pada pandangan atau persepsi terhadap pemenuhan kebutuhan informasi. Tanpa pengguna jasa suatu perpustakaan tidak akan bermakna. Karena itu pengguna merupakan unsur yang penting. Pengguna sudah mengeluarkan biaya, oleh sebab itu mereka mempunyai hak untuk mendapatkan pelayanan yang terbaik. Pustakawan sebagai orang yang bekerja di bidang penyediaan jasa informasi juga perlu menyadari akan hal ini.

Perpustakaan Fakultas Ilmu Komunikasi Unpad sebagai salah satu pusat informasi dan pengetahuan dalam bidang komunikasi dan informasi ilmiah mempunyai peranan penting dalam meningkatkan kualitas pengetahuan masyarakat, dan merupakan mata rantai komunikasi ilmiah antara pengguna dengan sumber informasinya. Dalam menjalankan tugas dan fungsinya sebagai pelayan masyarakat, Perpustakaan Fakultas Ilmu Komunikasi Unpad selalu mendapat perhatian yang khusus dari masyarakat penggunanya, baik tentang mutu layanan, kelengkapan koleksi, kenyamanan, kemudahan dalam memperoleh informasi serta penerapan teknologi informasi yang mempermudah dalam akses informasi. Hal ini tentunya tidak lepas dari nama besar Fakultas Ilmu Komunikasi sebagai Fakultas paling diminati dan terkenal di Unpad bahkan di Indonesia.

Untuk itu, Perpustakaan Fakultas Ilmu Komunikasi Unpad dituntut untuk dapat melaksanakan layanan yang diharapkan oleh penggunanya, yaitu Mahasiswa dan Dosen di Fikom Khususnya, maupun di Unpad bahkan di Indonesia pada umumnya. Sejalan dengan hal tersebut maka diperlukan penelitian yang dapat mengukur secara ilmiah tentang sejauhmana layanan yang diterima pengguna dari Perpustakaan Fakultas Ilmu Komunikasi Unpad. Namun demikian sangat perlu juga untuk mengetahui keinginan atau harapan mereka. Bertitik tolak dari hal ini, kiranya dapat diambil manfaatnya kedepan untuk menerapkan kebijakan layanan sesuai standar minimal yang diinginkan oleh pengguna, untuk meningkatkan kualitas atau mutu layanan yang akan diberikan kepada pengguna dengan melihat sisi lemah dan kuat dari dimensi masing-masing layanan untuk kemudian dicarikan solusi untuk peningkatan kualitas. Atau dapat juga dijadikan sebagai bahan evaluasi bagi penentuan kebijakan teknis layanan perpustakaan kedepannya.

Upaya untuk mengukur mutu layanan dapat diketahui dengan menggunakan beberapa instrumen seperti misalnya khusus untuk mengukur kualitas layanan di perpustakaan maka alat ukur yang kiranya lebih tepat adalah dengan menggunakan model LibQual $^{\mathrm{TM}}$. Model tersebut merupakan pengembangan dari model servqual yang telah dikembangkan terlebih dulu oleh Parasuraman, dkk. Model ServQual (service quality) berpedoman pada konsep kepuasan pengguna lewat kajian terhadap harapan dan persepsi mereka terhadap layanan yang diterima pengguna melalui 5 (lima) dimensi 
kualitas pelayanan. Sedangkan LibQual ${ }^{\mathrm{TM}}$ hanya pada 3 (tiga) dimensi kualitas layanan khusus di perpustakaan yakni affect of servises, library as place dan Information Control.

Saat ini Perpustakaan Fikom Unpad telah melakukan berbagai perubahan untuk dapat meningkatkan kualitas layanannya pada pengguna (sivitas akademika Fikom Unpad). Perbaikan pada penyediaan sarana fisik seperti pemindahan ruang ke gedung baru di gedung pascasarjana ilmu komunikasi sejak hampir tiga tahun lalu (sejak tahun 2013), kemudian penataan ruangan, penambahan fasilitas layanan seperti sarana multimedia, internet, RFID, dan penambahan koleksi telah dilakukan secara berkala dan terencana dengan cukup baik. Namun, apakah dengan adanya upaya perbaikan tersebut berarti telah mendongkrak kualitas layanan perpustakaan atau masih perlu dilakukan banyak hal lain lagi agar kualitas layanan perpustakaan di Fikom Unpad ini dapat diraih.

Dalam upaya memenuhi ekspektasi/harapan dan mewujudkan kepuasan pengguna, pihak perpustakaan perlu menyusun program peningkatan kualitas pelayanan untuk diterapkan secara lebih tepat dan terintegrasi. Sehubungan dengan hal tersebut kiranya yang menjadi pokok masalah dalam penelitian ini adalah bagaimana kualitas layanan Perpustakaan Fikom Unpad ditinjau dari dimensi Information Control, Affect of service dan dimensi Library as Place. Sehingga kepuasan pengguna perpustakaan dapat dilihat dari sejauhmana kualitas layanannya dengan memperhatikan ketiga dimensi tersebut diatas. Adapun manfaat penelitian ini adalah diharapkan dapat digunakan sebagai bahan masukan untuk bahan pertimbangan dalam penyusunan program pengembangan layanan, sebagai sumber informasi bagi pengambilan keputusan yang berkaitan dengan peningkatan kualitas layanan perpustakaan dan menjadi sumber referensi bagi pengembangan kajian manajemen kelembagaan perpustakaan dalam ilmu perpustakaan dan informasi.

Perpustakaan sebagai lembaga yang bergerak di bidang layanan informasi banyak mengaplikasikan berbagai metode untuk mengukur kualitas layanannya. Beberapa penelitian yang menggunakan Model Pengukuran ServQual sebagai instrumen penelitiannya sudah banyak digunakan oleh peneliti dalam bidang ilmu informasi dan perpustakaan. Model tersebut kemudian diadopsi, dikembangkan, dan diaplikasikan diperpustakaan oleh $A R L$ (Associations of Research Libraries) berkolaborasi dengan Texas A\&M University (TAMU) pada tahun 1999. Melalui penelitiannya, proyek penelitian tersebut kemudian menghasilkan instrumen untuk mengukur kualitas layanan perpustakaan yang kemudian populer dengan LibQual ${ }^{\mathrm{TM}}$ yang merupakan pengembangan dari dimensidimensi pada Model ServQual.

Dimensi kualitas layanan 
perpustakaan dalam penelitian ini menggunakan salah satu model pengukuran kualitas layanan yaitu model LibQual $^{\mathrm{TM}}$. Menurut Zeithaml, Parasuraman dan Berry (1990: hlm.16) bahwa pengguna-lah yang berhak menilai kualitas suatu layanan, penilaian selain oleh Anggota adalah tidak relevan. Anggota akan menyatakan kepuasannya terhadap kualitas sebuah layanan dilihat dari persepsi dan harapannya terhadap layanan tersebut. Berdasarkan hal itu, maka kualitas layanan perpustakaan dalam penelitian ini diukur melalui "harapan" dan "persepsi" Anggota Perpustakaan. Harapan adalah tingkat layanan yang dibutuhkan atau diinginkan Anggota. Sedangkan persepsi adalah tingkat layanan yang diterima atau dirasakan Anggota. Kesenjangan (GAP) antara "harapan" dan "persepsi" anggota inilah yang disebut dengan kualitas layanan perpustakaan dan akan berujung pada kepuasan anggota akan layanan yang ada.

Dengan model LibQual ${ }^{+\mathrm{TM}}$ dapat dianalisa tingkat kualitas yang diperoleh berdasarkan hasil pengukuran dan perbandingan antara layanan yang diharapkan (expected services) dan layanan yang diterima dan dipersepsikan oleh anggota (perceived service quality) pada berbagai dimensi layanan menurut LibQual $^{+\mathrm{TM}}$ seperti affect of services, information control dan library as place. Berdasarkan hal-hal diatas maka kerangka pemikiran dalam penelitian ini kiranya dapat digambarkan seperti dalam bagan berikut :

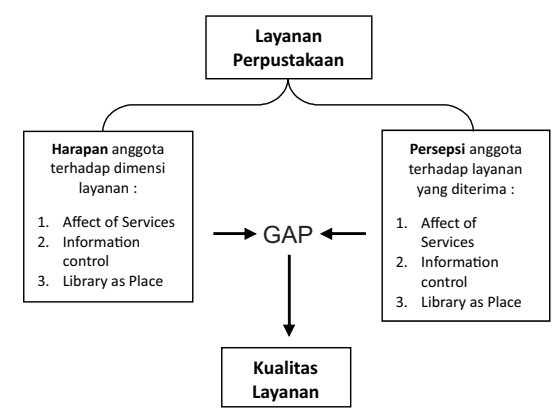

Bagan 1. Harapan dan Persepsi Pengguna pada Layanan Perpustakaan

Kualitas layanan yang baik akan memberikan suatu ransangan yang kuat kepada para Anggota untuk menggunakan jasa dari penyedia layanan tersebut. Kemampuan penyedia layanan dalam memahami kebutuhan Anggota akan membuat mereka mengerti apa yang menjadi harapan Anggota terhadap layanan sehingga penyediaan layanan dapat dengan tepat atau paling tidak sesuai dengan harapan anggotanya.

Adapun teori terapan (applied theory) yang menjadi landasan dalam penelitian ini adalah Expectation Confirmation Theory dari Oliver (1977, 1980). Dikenal juga dengan Expectation Disconfirmaton Theory (EDT). Teori ini menjelaskan kaitan antara kepuasan dengan ekspektasi, layanan yang diterima dan diskonfirmasi yang terjadi sebagai akibat dari kesenjangan antara harapan yang layanan yang diterima dan yang dipersepsikan oleh konsumen/Anggota terhadap dimensidimensi kualitas layanan. 
Jika digambarkan dalam sebuah bagan, maka teori EDT ini dapat dilihat sepertiberikut ini :

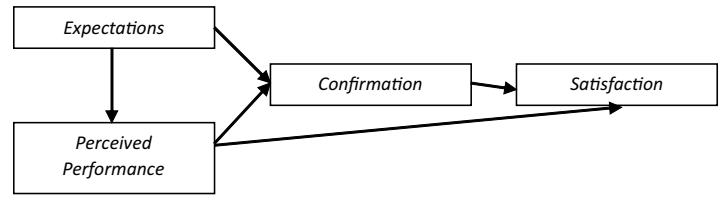

Bagan 2. Teori Expectation Disconfimation Theory (EDT)

Teori ini berpendapat bahwa harapan, ditambah dengan kinerja yang dirasakan, mengarah pada kepuasan pasca pembelian/pelayanan. Pengaruh ini ditengahi melalui diskonfirmasi positif atau negatif antara harapan dan kinerja. Jika sebuah produk melebihi harapan (positif disconfirmation) pasca-pembelian/pelayanan akan menghasilkan kepuasan. Jika sebuah produk gagal dari harapan (negatif disconfirmation), maka konsumen cenderung tidak puas (Oliver, 1980; Spreng et al. 1996). Empat konstruksi utama dalam model ini adalah : harapan, kinerja, diskonfirmasi, dan kepuasan. Harapan mencerminkan perilaku yang harus diantisipasi (Churchill dan Suprenant, 1982). Harapan harus dapat diprediksi, menunjukkan atribut produk yang diharapkan pada suatu saat di masa depan (Spreng et al. 1996). Harapan berfungsi sebagai standar perbandingan dalam Expectation Confirmation Theory. Penerapan dari teori ini juga digunakan bagi konsumen untuk mengevaluasi kinerja dan membentuk penentuan diskonfirmasi (Halstead, 1999). Diskonfirmasi diduga dapat mempengaruhi kepuasan. Diskonfirmasi positif menuju pada kepuasan, sedangkan diskonfirmasi negatif menuju pada ketidakpuasan konsumen/Anggota.

Teori EDT diatas sangat terkait dengan teori disonansi kognitif (Cognitive Dissonance Theory). Menurut teori disonansi kognitif, ada kecenderungan bagi individu untuk mencari konsistensi antara kognisi mereka (yaitu, kepercayaan, pendapat). Ketika ada ketidaksesuaian antara sikap atau perilaku (disonansi), sesuatu harus berubah (diperbaiki) untuk menghilangkan disonansi tersebut.

Teori EDT juga terkait dengan teori pertukaran sosial (Social Exchange Theory). Menurut Hormans (1958), inisiator dari teori ini, bahwa teori ini dikembangkan untuk memahami perilaku sosial manusia dalam kegiatan ekonomi. Perbedaan mendasar antara pertukaran ekonomi dan teori pertukaran sosial adalah dalam cara melihat 'sang' aktor. Teori pertukaran sosial memandang hubungan pertukaran antara aktor tertentu sebagai "tindakan yang tergantung pada reaksi bermanfaat dari orang lain" (Blau, 1964, P.91.)

Variabel bebas dalam penelitian ini adalah kualitas layanan perpustakaan di Perpustakaan Fikom Unpad itu sendiri. Variabel penelitian yang diamati atau yang akan diukur dalam penelitian ini adalah dapat dipaparkan pada operasionalisasi konsep dalam tabel sebagai berikut : 
Tabel 1. Operasionalisasi Variabel Penelitian

\begin{tabular}{|c|c|c|}
\hline Variabel & Sub variabel & Indikator \\
\hline \multirow[t]{3}{*}{$\begin{array}{l}\text { Kualitas } \\
\text { layanan }\end{array}$} & $\begin{array}{c}\text { Harapan dan } \\
\text { persepsi pengguna } \\
\text { terhadap } \\
\text { Information Control }\end{array}$ & $\begin{array}{l}\text { 1. } \text { akses penggunaan fasilitas cepat } \\
\text { dan mudah } \\
\text { 2. Ketersediaan koleksi yang sesuai } \\
\text { dengan kebutuhan } \\
\text { 3. Fasilitas mudah digunakan } \\
\text { 4. Kelengkapan koleksi yang } \\
\text { memadai } \\
\text { 5. Informasi terbaru (up to date) } \\
\text { 6. Stafsirkulasi selalu ada ditempat } \\
\text { ketika dibutuhkan } \\
\text { 7. Kejelasan petunjuk Penggunaan } \\
\text { OPAC (online public access } \\
\text { catalogue) } \\
\text { 8. Kemudahan dalam penelusuran } \\
\text { buku pada OPAC } \\
\text { 9. Kejelasan petunjuk peminjaman } \\
\text { dan pengembalian buku } \\
\text { 10. Kemudahan mencari buku di rak. } \\
\text { 11. Kemudahan pencarian informasi } \\
\text { malalui internet }\end{array}$ \\
\hline & $\begin{array}{c}\text { Harapan dan } \\
\text { persepsi Pengguna } \\
\text { Terhadap Affect of } \\
\text { service: }\end{array}$ & $\begin{array}{l}\text { 12. Stafsirkulasi selalu ada ditempat } \\
\text { ketika dibutuhkan } \\
\text { 13. Keramahtamahan, perhatian dan } \\
\text { kesopanan staf. } \\
\text { 14. Kecepatan dalam pelayanan } \\
\text { 15. Sikap tanggap stafpada pengguna } \\
\text { dalam mencari informasi } \\
\text { 16. Kemampuan berkomunikasi staf } \\
\text { dengan baik }\end{array}$ \\
\hline & $\begin{array}{c}\text { Harapan dan } \\
\text { persepsi pengguna } \\
\text { terhadap library as } \\
\text { place }\end{array}$ & $\begin{array}{l}\text { 17. Ketersediaan Ruangan internet } \\
\text { yang memadai } \\
\text { 18. Pencahayaan ruangan perpustakaan } \\
\text { 19. Ketenangan dan kenyamaan } \\
\text { ruangan } \\
\text { 20. Lokasi perpustakaan yang mudah } \\
\text { dijangkau } \\
\text { 21. Ketersediaan fasilitas ruangan (AC, } \\
\text { meja, kursi, loker yang memadai) }\end{array}$ \\
\hline
\end{tabular}

Untuk menghitung sejauhmana kualitas layanan berdasarkan operasionalisasi variabel diatas maka data hasil penyebaran kuesioner dihitung dengan ketentuan berikut :

1. Menghitung jumlah skor harapan minimum, total skor harapan yang diinginkan (Desired) dan total skor persepsi (Perceived) untuk setiap butir pertanyaan.

2. Menghitung skor rata-rata minimum harapan yang diinginkan (Desired) dan skor rata-rata minimum persepsi (Perceived)

3. Membandingkan skor rata-rata minimum harapan yang diinginkan (Desired) dan skor rata-rata minimum persepsi
(Perceived) sehingga diperoleh skor kesenjangan (GAP) untuk mengetahui kualitas layanan.

Rumus yang digunakan untuk mendapatkan skor kesenjangan (GAP) adalah sebagai berikut :

$\mathrm{AG}=$ Perceived (Persepsi) - Minimum Desired (Harapan Minimum)

SG $=$ Perceived (Persepsi) - Desired (Harapan yang diinginkan)

Keterangan :

- Apabila skor SG (Superiority Gap) menunjukan nilai positif maka layanan yasng diberikan telah melebihi harapan pengguna, dapat diartikan pula bahwa pengguna sangat puas terhadap layanan yang diterimanya.

- Apabila skor SG (Superiority Gap) menunjukan nilai negatif maka hal ini berada pada 'Zone of Tolerance' perpustakaan belum mampu memenuhi harapan sesungguhnya dari pengguna dengan berarti perpustakaan belum memberikan layanan dengan kualitas yang unggul.

- Apabila skor AG (Adequacy Gap) menunjukan nilai positif maka layanan yang diberikan telah memenuhi harapan pengguna dengan kata lain kualitas layanan dinyatakan cukup puas bagi pengguna/responden.

- Apabila skor AG (Adequacy Gap) menunjukan nilai negatif maka layanan yang diberikan belum 
memenuhi harapan pengguna, dengan demikian pengguna tidak puas terhadap layanan yang diberikan.

Dengan menggunakan rumus tersebut, maka tingkat kepuasan pengguna sebagai variabel terikat dalam penelitian ini dapat diketahui. Dalam hal ini puas maupun tidaknya pengguna perpustakaan amat bergantung pada sejauhmana kualitas layanan perpustakaan, dimana nilai persepsi dan harapan pengguna menjadi acuannya.

Metode Penelitian yang digunakan dalam penelitian ini adalah Metode Deskriptif. Penelitian ini merupakan upaya untuk mengungkapkan suatu hal yang terjadi pada saat penelitian dilakukan sebagai masalah yang aktual. Oleh karena itu maka dalam penelitian ini digunakan metode deskriptif sebagai suatu prosedur untuk mengetahui dan memecahkan masalah yang dihadapi. Menurut Rakhmat (2005 : hlm. 24-25) bahwa metode penelitian deskriptif adalah metode yang melukiskan berbagai variabel, satu demi satu, secara komprehensif, sistematis, dan akurat. Sedangkan alat ukur yang digunakan agar variabel yang akan diteliti dapat digambarkan secara komprehensif dan ukuran kualitas layanan yang diteliti dapat diketahui nilainya secara akurat, maka dalam penelitian ini dgunakan model LibQual ${ }^{+\mathrm{TM}}$ dari ARL dan Texas A\&M University sebagai model pengukuran kualitas layanan dan kepuasan pengguna perpustakaan.

Populasi dalam penelitian ini adalah
Anggota Perpustakaan Fikom Unpad yang telah terdaftar menjadi anggota. Berdasarkan data yang terdapat di Perpustakaan dan Sub Bagian Pendidikan Fikom Unpad diketahui bahwa jumlah anggota perpustakaan yang telah terdaftar adalah sebanyak 3822 orang mahasiswa. Dari jumlah tersebut, secara spesifik anggota perpustakaan yang memanfaatkan layanan Perpustakaan Fikom Unpad ditetapkan pada seluruh mahasiswa Fikom Unpad yang ada hingga saat penelitian ini dilaksanakan. Sehingga populasi dalam penelitian ini adalah hanya anggota perpustakaan pada kategori mahasiswa Fikom Unpad secara keseluruhan mulai dari Program Diploma hingga Pascasarjana.

Sampel merupakan representasi dari populasi (Singarimbun dan Effendy, 1989 : 54). Semakin banyak sampel yang dipilih maka semakin sampel itu bisa menggambarkan populasi, sehingga taraf kesalahannya bisa dihindari seminimal mungkin. Namun, peneliti dalam hal ini juga mempertimbangkan faktor waktu selama melaksanakan penelitian ini.

Dengan menggunakan rumus rumus Yamane (Rakhmat 2009, 82), maka ukuran sampel dalam penelitian ini adalah :

keterangan :

$\mathrm{n}$ : jumlah sampel

$\mathrm{N}$ : jumlah populasi

d : tingkat perkiraan kesalahan $10 \%$, selang kepercayaan $90 \%$ 


$$
\begin{array}{ll}
\mathbf{n}= & 3822 \\
& 3822(0.1)^{2}+1 \\
\mathbf{n}= & 3822 \\
& 39.22 \\
\mathbf{n}= & 97.45 \text { sampel } \approx 98 \text { orang } \\
& \text { responden }
\end{array}
$$

Jadi sampel dalam penelitian ini akan diambil sebanyak 98 orang dari populasi 3822 orang yang diambil dari jumlah Anggota Perpustakaan Fikom Unpad.

\section{PEMBAHASAN}

Berdasarkan hasil penelitian maka dapat dianalisis secara umum tentang sejauh mana kualitas layanan perpustakaan Fikom Unpad. Dari hasil perhitungan menunjukan bahwa nilai rata-rata harapan minimum yaitu 5,59 . Sedangkan nilai rata-rata harapan yang sesungguhnya (desired) yaitu 7,88. Berikutnya nilai rata-rata persepsi yaitu 6,57. Data diatas menunjukkan bahwa nilai ratarata persepsi lebih tinggi dari harapan minimum. Dengan demikian diperoleh nilai kesenjangan AG (Adequacy Gap) positif yaitu 0,98 dan nilai SG (Superiority Gap) - 1,31. Hasil analisis data dapat dilihat pada tabel berikut:

Tabel 2. Hasil Analisis Secara Umum

\begin{tabular}{|c|c|c|c|c|c|}
\hline $\begin{array}{c}\text { 21 Butir } \\
\text { Pernyataan }\end{array}$ & $\begin{array}{c}\text { Harapan } \\
\text { Minimum }\end{array}$ & $\begin{array}{c}\text { Harapan } \\
\text { Sesungguhnya }\end{array}$ & Persepsi & $\begin{array}{c}\text { Adequacy } \\
\text { Gap (AG) }\end{array}$ & $\begin{array}{c}\text { Superiority } \\
\text { Gap (SG) }\end{array}$ \\
\hline Rata-Rata & 5.59 & 7.88 & 6.57 & 0.98 & -1.31 \\
\hline
\end{tabular}

Angka 0,98 tersebut menunjukkan bahwa nilai Adequacy Gap memperoleh nilai positif. Hal tersebut berarti bahwa kualitas layanan berada diatas skor rata-rata harapan minimum responden. Nilai tersebut juga menunjukkan bahwa pengguna menilai kualitas layanan yang diterimanya sudah cukup berkualitas dan memenuhi harapan minimum yang diinginkan. Dengan demikian maka dapat disimpulkan bahwa pengguna perpustakaan merasa cukup puas dengan layanan yang diberikan oleh Perpustakaan Fikom Unpad.

Nilai Superiority Gap (SG) secara umum masih memperoleh nilai negatif. Namun tidak terlalu rendah dibawah nilai rata-rata harapan minimum. Artinya nilai SG masih berada pada wilayah yang ditolerir (zone of tolerance) pengguna. Pengguna sudah cukup merasa puas dan menilai bahwa layanan sudah cukup berkualitas. Upaya yang hingga saat ini telah dilakukan oleh Fikom Unpad beserta para pengelola perpustakaannya dalam memperbaiki fasilitas, koleksi dan layanan perpustakaan sudah mendapat apresiasi yang cukup baik dari para penggunanya, terutama mahasiswa Fikom Unpad sebagai stakeholder utama perpustakaan Fikom Unpad.

Upaya tersebut tentunya dapat dilihat dari adanya perbaikan penataan ruang perpustakaan, penambahan sarana-prasarana di perpustakaan serta penambahan koleksi bahan pustaka serta sumber-sumber informasi di perpustakaan. Pengguna sudah merasa lebih nyaman, tertarik untuk berkunjung dan memanfaatkan perpustakaan serta pelayanan yang diterima olehnya dari para staf perpustakaan sudah jauh lebih baik. Secara umum pengguna sudah merasa cukup puas dengan adanya perubahan kualitas layanan 
perpustakaan yang kini mengarah pada perbaikan dan peningkatan.

Kepuasan pengguna sendiri adalah tingkat kepuasan yang telah dirasakan (perceived) oleh pengguna sebagai pengguna jasa perpustakaan atas pelayanan yang telah diberikan oleh perpustakaan dibandingkan dengan apa yang mereka harapkan (expected) dari pelayanan tersebut. Sebagaimana pendapat Parasuraman, Zeithaml dan Berry (1985) yang menyatakan bahwa : "ada dua faktor utama yang mempengaruhi kualitas layanan, yaitu expected service dan perceived service".

Kotler (2003) juga memberikan pernyataan bahwa : "kualitas harus dimulai dari kebutuhan pelanggan dan berakhir pada persepsi pelanggan." Sebagaimana prinsip dari LibQual ${ }^{+\mathrm{TM}}$ (2008) yakni : "hanya pengguna yang berhak menilai kualitas layanan". Sehingga dalam hal ini ukuran dari kualitas layanan yang baik bukanlah berdasarkan pada sudut pandang atau persepsi pihak pengelola perpustakaan sebagai penyedia layanan, melainkan berdasarkan sudut pandang atau persepsi penggunanya. Dengan demikian, sekali lagi bahwa secara umum dapat dikatakan kualitas layanan perpustakaan Fikom Unpad sudah cukup memuaskan penggunanya, terutama mahasiswa Fikom Unpad. Namun hal ini harus terus ditingkatkan dimasa-masa yang akan datang. Terlebih jika kita lihat bahwa nilai rata-rata Superiority Gap (SG) masih memperoleh nilai negatif.

Selanjutnya, analisis pada setiap dimensi kualitas layanan perpustakaan dengan menggunakan indikator pengukuran dengan tiga dimensi layanan perpustakaan sesuai dengan model LibQual ${ }^{+\mathrm{TM}}$ yaitu :

1. Information Control, yakni meliputi ketersediaan koleksi dan kemudahan mengakses informasi. Dalam kuesioner dimensi ini meliputi sebelas pernyataan.

2. Affect of Service, yakni kemampuan dan sikap stafperpustakaan dalam melayani pengguna. Dalam kuesioner dimensi ini mencakup lima pernyataan.

3. Library as Place, yakni perpustakaan sebagai sebuah tempat. Dalam kuesioner dimensi ini meliputi lima pernyataan.

Analisis berdasarkan dimensi kualitas layanan ini didapat dengan cara menjumlahkan semua skor harapan minimum, harapan yang sesungguhnya dan persepsi, kemudian dibagi dengan jumlah butir pernyataan pada masing-masing dimensi, sehingga diketahui nilai rata-rata harapan minimum, harapan sesungguhnya (desired) dan nilai rata-rata persepsi.

Dari hasil pengukuran pada dimensi Information Control, diperoleh hasil bahwa nilai rata-rata tertinggi adalah pada nilai harapan yang sesungguhnya (desired) yaitu 7,93 . Nilai skor harapan minimum yaitu 5,41 dan skor rata-rata persepsi adalah 6,33. Data tersebut menunjukkan bahwa nilai rata-rata persepsi lebih tinggi dari harapan minimum, sehingga memperoleh nilai kesenjangan 
(Adequacy Gap/AG) yang cukup positif yaitu 0,91. Sedangkan nilai Superiority Gap (SG) diperoleh nilai negatif yakni - 1,60. Hal serupa juga terjadi pada kedua dimensi lainnya yang masing-masing menunjukkan nilai rata-rata persepsi lebih tinggi dari harapan minimum. Hasil analisis data dapat dilihat pada tabel 1.8 dihalaman berikut ini :

Tabel 3. Hasil Analisis Data Berdasarkan

Dimensi Kualitas Layanan

\begin{tabular}{|l|c|c|c|c|c|}
\hline \multicolumn{1}{|c|}{$\begin{array}{c}\text { Dimensi Kualitas } \\
\text { Layanan }\end{array}$} & $\begin{array}{c}\text { Harapan } \\
\text { Minimum }\end{array}$ & $\begin{array}{c}\text { Harapan } \\
\text { Sesungguhnya }\end{array}$ & Persepsi & AG & SG \\
\hline $\begin{array}{l}\text { Ketersediaan Koleksi } \\
\text { dan Kemudahan } \\
\text { Akses Informasi } \\
\text { (Information } \\
\text { Control) }\end{array}$ & 5.41 & 7.93 & 6.33 & 0.91 & -1.60 \\
\hline $\begin{array}{l}\text { Sikap dan } \\
\text { kemampuan } \\
\text { stafdalam melayani } \\
\text { pengguna (Affect of } \\
\text { Service) }\end{array}$ & 5.51 & 7.82 & 6.51 & 0.99 & -1.32 \\
\hline $\begin{array}{l}\text { Perpustakaan sebagai } \\
\text { sebuah tempat } \\
\text { (Library as Place) }\end{array}$ & 5.83 & 7.87 & 6.88 & 1.04 & -1.00 \\
\hline
\end{tabular}

Pada tabel diatas dapat dilihat bahwa dimensi kualitas layanan yang paling tinggi nilai kualitasnya adalah dimensi Library as Place (yaitu perpustakaan sebagai sebuah tempat) yang memperoleh nilai/skor AG 1.04 dan skor SG-nya yakni -1.00. Dimensi berikutnya yakni Affect of Services (yaitu sikap dan kemampuan staf dalam melayani pengguna) memperoleh skor rata-rata AG 0,99 dan Skor $\mathrm{SG}-1,32$.

Adequacy Gap pada setiap dimensi menunjukkan positif dan berada diatas nilai rata-rata harapan minimum berarti kualitas layanan dikatakan cukup baik. Hal tersebut juga menunjukkan bahwa pengguna menilai kualitas layanan berdasarkan tiga dimensi yang diterimanya sudah cukup memenuhi harapan minimum yang diinginkan sehingga pengguna dapat dikatakan cukup puas dengan layanan yang diberikan. Dengan demikian, dapat dikatakan, bahwa berdasarkan tiga dimensi kualitas layanan perpustakaan tersebut, responden menyatakan bahwa layanan di Perpustakaan Fikom Unpad sudah cukup berkualitas dan cukup memuaskan mereka.

Kualitas layanan berpusat pada upaya pemenuhan kebutuhan dan keinginan pengguna. Menurut Goetsh dan Davis dalam Arief (2007) "kualitas layanan merupakan suatu kondisi dinamis yang berhubungan dengan produk, jasa, manusia, proses dan lingkungan yang memenuhi atau melebihi harapan". Sedangkan Kotler (2003) menegaskan bahwa keseluruhan layanan berpengaruh pada kemampuan untuk memuaskan kebutuhan.

Dengan berpatokan pada ketiga dimensi kualitas layanan LibQual ${ }^{+\mathrm{TM}}$ maka kualitas layanan perpustakaan dapat diukur. Persepsi dan harapan pengguna terhadap kualitas layanan perpustakaan itu sangat mempengaruhi kepuasan pengguna. Dimensi sikap dan kemampuan stafdalam melayani pengguna (Affect of Service) sangat penting dalam mewujudkan layanan yang baik dan prima. Sikap dan perhatian adalah dasar bagi stafperpustakaan untuk memberikan pelayanan secara nyata. Begitu juga dimensi ketersediaan koleksi perpustakaan dan kemudahan akses informasi di perpustakaan (Information Control) juga sangat jelas dibutuhkan pengguna serta tersedianya 
fasilitas perpustakaan sebagai sebuah tempat (Library as Place) yang memadai sangat mempengaruhi kenyamanan dan ketertarikan pengguna untuk memanfaatkan layanan perpustakaan.

Pada kasus yang terjadi di Perpustakaan Fikom Unpad, dimensi layanan yang paling berkontribusi memberikan kepuasan pengguna adalah dimensi Library as Place. Kondisi ruangan dan fasilitas yang dimiliki oleh Perpustakaan Fikom sudah cukup memenuhi harapan dan cukup ideal sebagai sebuah perpustakaan perguruan tinggi. Meski tidak terlalu luas, namun kondisi ruang perpustakaan sudah cukup nyaman, bersih dan tertata rapih. Fasilitas ruang baca sudah cukup memadai, peralatan dan suasana ruangan sudah cukup nyaman membuat pengguna merasa betah ketika berada didalam ruang perpustakaan. Ketersediaan pengatur udara (Air Conditioning) juga cukup membuat pengguna merasa nyaman selama berada di perpustakaan. Perpustakaan Fikom Unpad juga menyediakan fasilitas yang tidak disediakan di perpustakaan fakultas lain di Unpad seperti Koleksi Bacaan Populer, Alat Permainan, Televisi Kabel, serta Sarana RFID (Radio Frequency Identification) untuk kemudahan pelayanan sirkulasi dan alat keamanan koleksi. Selain itu, fasilitas komputer juga disediakan cukup banyak bagi mahasiswa yang perlu menggunakan itu dalam mengerjakan tugas maupun penelusuran informasi online.

Dimensi lainnya yakni ketersediaan akses informasi dan koleksi bahan pustaka (Information Control) juga dinilai cukup memenuhi kepuasan pengguna. Jumlah koleksi buku, jurnal ilmiah dan koleksi referensi lainnya di perpustakaan Fikom Unpad sudah dinilai cukup memenuhi kebutuhan pengguna. Mereka beranggapan bahwa koleksi di perpustakaan Fikom Unpad sudah cukup lengkap dan memadai. Diantara dimensi lainnya, dimensi Information Control ini memperoleh nilai/skor AG paling kecil, meski sudah berada pada nilai positif. Aspek koleksi dan akses terhadap sumber-sumber informasi di perpustakaan jika melihat hasil penilaian ini maka sebaiknya menjadi fokus perhatian utama/prioritas utama untuk dikembangkan. Pengguna masih berharap bahwa koleksi dan akses informasi dapat dilengkapi dan ditambah lagi sehingga dapat memenuhi kebutuhan informasi mereka. Terutama untuk mendukung optimalisasi kegiatan belajar/kuliah selama di Fikom Unpad. Namun ketersediaan fasilitas, sarana/prasarana pendukung serta aspek pelayanan dari staf maupun pustakawan dapat juga terus ditingkatkan.

Dimensi affect of service dalam penelitian ini juga dinilai cukup memuaskan pengguna perpustakaan Fikom unpad dengan skor AG 0,99. Hal ini mungkin dikarenakan stafperpustakaan (untuk menyebut bukan fungsional pustakawan) di Fikom Unpad selalu ada ketika pengguna membutuhkan bantuan mereka. Petugas/staf perpustakaan selalu berada di tempat pada jam-jam buka layanan dan siap membantu manakala 
pengguna ingin dilayani. Sikap yang ditunjukkan staf perpustakaan juga sudah cukup baik menurut pengguna manakala mereka berinteraksi dengan pengguna dalam kegiatan pelayanan perpustakaan. Pelayanan dari aspek/dimensi ini tentunya diharapkan menjadi perhatian juga dari Fakultas Ilmu Komunikasi Unpad.

Peningkatan kualitas, kapasitas serta kemampuan staf perpustakaan dalam memberikan pelayanan baik secara teknis maupun non teknis sebaiknya menjadi perhatian Fakultas. Mengingat sebagus dan selengkap apapun perpustakaan, tanpa didukung oleh pelayanan yang baik (Prima) dari para staf layanan tentunya akan sangat mempengaruhi penilaian kualitas serta kepuasan pengguna dari aspek-aspek lainnya. Erwina (2016) berpendapat bahwa ujung tombak layanan perpustakaan sebetulnya adalah pada saat terjadinya interaksi antara pengguna dengan staf terlebih dulu, bukan dengan hal-hal lainnya di perpustakaan. Boleh jadi koleksi perpustakaan masih terbatas, fasilitas masih sedikit dan sederhana, namun jika staf mampu memberikan layanan yang sangat baik dan prima, maka pengguna tetap akan merasa puas dilayani. Mereka akan merasa nyaman diperlakukan sebagai pengguna. Merasa dihargai kedatangan dan keberadaannya di perpustakaan.

\section{SIMPULAN}

Penelitian ini menghasilkan suatu kesimpulan bahwa secara umum kualitas layanan di Perpustakaan Fikom Unpad dinilai sudah cukup berkualitas serta memenuhi harapan minimum pengguna. Pengguna cukup puas dengan layanan yang diberikan oleh Perpustakaan Fikom Unpad.

Kualitas layanan pada dimensi information control (ketersediaan informasi dan kemudahan akses informasi) sudah cukup berkualitas. Berdasarkan hasil penelitian diketahui bahwa nilai rata-rata persepsi responden pada dimensi kualitas layanan ini berada diatas nilai rata-rata harapan minimum pengguna. Koleksi yang ada di perpustakaan Fikom Unpad kini sudah jauh lebih baik dan selalu ada penambahan setiap tahunnya sesuai dengan kebutuhan dan permintaan pengguna. Ketersediaan beragam jenis koleksi serta adanya akses informasi menggunakan internet membuat pengguna merasa cukup puas dengan layanan yang diberikan oleh Perpustakaan Fikom Unpad.

Kualitas layanan pada dimensi Affect of Service (kemampuan dan sikap staf dalam melayani pengguna) juga sudah dapat dikatakan cukup berlualitas. Hasil penelitian menunjukkan bahwa nilai rata-rata persepsi responden pada dimensi ini berada diatas nilai rata-rata harapan minimum. Staf perpustakaan memegang peranan penting dalam menunjang layanan perpustakaan. Untuk itu Perpustakaan Fikom Unpad senantiasa berupaya agar staf Perpustakaan mampu memberikan pelayanan yang prima.

Dimensi Library as Place (tempat/ruang serta fasilitas layanan di perpustakaan) juga memperoleh penilaian yang cukup positif. Hal ini berarti responden 
(pengguna) merasa sudah cukup puas dengan aspek layanan ini. Responden menilai bahwa ruang layanan perpustakaan cukup memadai, nyaman dan representative sebagai sebuah ruang Perpustakaan tingkat fakultas. Upaya penataan yang hingga kini telah dilakukan menjadi salah satu hal yang mendapat apresiasi cukup positif dari para pengguna.

Berdasarkan kesimpulan dari hasil penelitian yang telah dilakukan dan maka kiranya saran serta masukan bagi Fakultas Ilmu Komunikasi Unpad sebagai lembaga penaung Perpustakaan di tingkat Fakultas untuk meningkatkan kualitas layanannya pada pengguna dengan memperhatikan aspek-aspek seperti penyediaan koleksi yang lebih lengkap, mutakhir, memadai serta sesuai dengan kebutuhan pengguna. Selain itu akses informasi dari sumber-sumber elektronik dan bahan digital maupun internet sebaiknya mendapat perhatian untuk dapat lebih dikembangkan penyediaan sarana maupun prasarananya.

Pada aspek staf perpustakaan, diharapkan adanya upaya peningkatan kualitas maupun kuantitas staf pengelola. Saat ini perpustakaan Fikom Unpad sudah memiliki staf fungsional Pustakawan. Namun jumlahnya hanya tiga orang sehingga masih jauh dari rasio kecukupan jumlah fungsional pustakawan yang dapat melayani jumlah mahasiswa dan Dosen di Fikom Unpad yang banyak. Keberadaan staf fungsional tersebut tentunya diharapkan dapat meningkatkan kualitas layanan serta bertanggung jawab dalam hal pengembangan perpustakaan sesuai dengan bidang keilmuan di bidang informasi dan perpustakaan. Selain itu, upaya peningkatan kemampuan staf juga perlu diupayakan diselenggarakannya kegiatankegiatan pelatihan/bimbingan teknis maupun mengikuti kegiatan tersebut yang diselenggarakan oleh lembaga/institusi lain.

Ketersediaan ruangan, sarana maupun prasarana merupakan hal yang juga sangat penting di perpustakaan. Agar dapat menunjang peningkatan kualitas layanan maka penyediaan berbagai sarana maupun prasarana penunjang layanan seperti hardware, software maupun furniture yang lebih nyaman dan aman perlu disediakan secara lebih memadai. Ruang baca juga sebaiknya dapat disediakan lebih leluasa sehingga dapat menampung jumlah pengunjung yang lebih banyak sesuai dengan rasio ketersediaan meja-kursi baca dengan jumlah anggota perpustakaan.

\section{DAFTAR PUSTAKA}

Arikunto, Suharsimi. (2001). Prosedur Penelitian, Suatu Pendekatan Praktek. Jakarta : Rineka Cipta.

Blau,P. (1964). Exchange and Power in Social Life. New York: Wiley.

Diamond, Randy \& Martha Dragich. (Winter, $2001)$. Profesionalism in Librarianship: Shifting the Focus From Malpractice to Good Practice, dalam Library Trends, Ethical Issues of Information Technology oleh Robert G. Wengert (Ed). University of Illinois Graduate School of Library 
and Information Science.

Emerson, R. (1962). Power-Dependence Relations. American Sociological Review, 27(1):31-41.

Festinger, L. A. (1957). Theory of Cognitive Dissonance. Stanford University Press, Stanford, CA.

Fox, Harrold W. (2001). Business Library : Understanding Your Customer. US Small Business Administration, 1-9.

Gasperz, Vincent. (2002). Manajemen Kualitas Dalam Industri Jasa. Jakarta : Kerjasama Yayasan Indonesia Emas, Institut Vincent dengan PT. Gramedia Pustaka Utama.

Homans,G.C. (1958). Social Behavior as Exchange. American Journal of Sociology, 63 (6): 597-606.

Kotler, Philip. (2000). Marketting Management, Analisis, Planning and Implementation. Eight Edition. New Jersey. Prentice Hall, Englewood Cliffs.

Nazir, Mohammad.(2001). Metode Research. Jakarta, Ghalia Indonesia.

Neuman, W. Lawrence. (2000). Social Research Methods Qualitative and Quantitative Approaches. $4^{\text {th }}$ edition. Needham Height, MA : Allyn and Bacon.

Oliver R. L. (1977). Effect of Expectation and Disconfirmation on Postexposure Product Evaluations - an Alternative Interpretation. Journal of Applied Psychology, 62(4), p. 480.

Oliver R. L. (1980). A Cognitive Model of the
Antecedents and Consequences of Satisfaction Decisions. JMR, Journal of Marketing Research, 17(3), p. 460. Perpustakaan Nasional RI. (2002). Pedoman

Teknis Layanan Perpustakaan Nasional RI. Jakarta : Perpustakaan Nasional RI.

Setiawan Budi. (2006). Statistika dalam Penguraian dan Pemecahan Masalah Manajemen Publik dan Bisnis. Bandung: STIA-LAN.

Singarimbun, Masri dan Efendi, Sofyan. (2000). Metode Penelitian Survei. Yogyakarta, BPFE.

Singarimbun, Masri. (1989). Metode dan Proses Penelitian. Dalam Masri Singarimbun dan Sofian Effendi, 313. "Metode Penelitian Survai". Jakarta : LP3ES.

Spreng R. A. S.B. MacKenzie and R.W. Olshavsky, (1996). A Reexamination of the determinants of consumer satisfaction. Journal of Marketing, 60(3), p. 15.

Sugiyono. (2007). Metode Penelitian Administrasi. Bandung : $\mathrm{CV}$ Alfabeta.

Rakhmat, Djalaluddin. (2005). Metode Penelitian Komunikasi. Bandung : Remaja Rosda Karya.

Tjiptono, Fandy. (2008). Service Management : Mewujudkan Layanan Prima. Yogyakarta: Penerbit Andi. 